\title{
Villains Called Sicarii: A Commonplace for Rhetorical Vituperation in the Texts of Flavius Josephus
}

\author{
Marijn J. Vandenberghe \\ Ghent University, Faculty of Arts and Philosophy, \\ Department of History, Sint-Pietersnieuwstraat 35, 9000 Gent, Belgium \\ MarijnJ.Vandenberghe@UGent.be
}

\begin{abstract}
Examining the presentation of sicarii in Flavius Josephus's Judean War from a rhetorical perspective, this article argues that each reference to sicarii alludes to the clauses of a Roman law concerning sicarii, which Josephus has used as a commonplace for rhetorical vituperation against particular groups. Three literary-rhetorical tendencies of War are highlighted to show how this vituperation, as well as the connection between War's sicarii and the so called Fourth Philosophy, is part of a general rhetorical strategy to shift the blame for the outbreak of the violent conflict to one particular rebel group.
\end{abstract}

\section{Keywords}

Sicarii - Flavius Josephus - Jewish revolt (66-70 CE) - ancient rhetoric vituperation

The sicarii are an antagonistic group in the Judean War of Flavius Josephus. ${ }^{1}$ They are best known from the episode of their mass-suicide at the fortress of

* I am grateful to Peter Van Nuffelen and Mladen Popović for their assistance and Steve Mason and Jan Willem van Henten for their valuable comments on an earlier draft of this paper. All shortcomings and mistakes are my own.

1 All translated quotes from Josephus's Judean War and Antiquities throughout this paper are taken—with minor adaptions that are indicated—from Josephus, translated by Henry St. J. Thackeray et al., 10 vols., LCL (Cambridge: Harvard University Press, 1926-1965).

(C) KONINKLIJKE BRILL NV, LEIDEN, 2016 | DOI 10.1163/15700631-12340462 
Masada, the last bulwark of the Judean rebels in Judea. The narrative has fired imagination so much that it became a myth in modern Israeli nationalism with the credo "Masada shall not fall again."2 Some scholars have helped to revive the myth, while others have cast doubt on it. A classical view sees the sicarii as a radical wing within a larger movement of Judean freedomfighters, called the Zealots. ${ }^{3}$ Critics of this view have shown that Josephus distinguishes between the sicarii and the Zealots as two different groups. ${ }^{4}$ Others have pointed out that Josephus characterises the sicarii as villains, not as heroic freedom-fighters, while still others have questioned the credibility of his account. ${ }^{5}$ Most disagreements centre on some complexities in War's

2 See Nachman Ben-Yehuda, The Masada Myth: Collective Memory and Mythmaking in Israel (Madison: The University of Wisconsin Press, 1995).

3 See esp. Martin Hengel, "Zeloten und Sikarier: Zur Frage nach der Einheit und Vielfalt der jüdischen Befreiungsbewegung 6-74 nach Christus," in Josephus-Studien: Untersuchungen zu Josephus, dem antiken Judentum und dem Neuen Testament, Otto Michel zum 7o. Geburtstag gewidmet, ed. Otto Betz, Klaus Haacker, and Martin Hengel (Göttingen: Vandenhoeck \& Ruprecht, 1974), 175-96; Martin Hengel, Die Zeloten: Untersuchungen zur jüdischen Freiheitsbewegung in der Zeit von Herodes I. bis 70 n. Chr., AGSU 1 (Leiden: Brill, 1961); Yigael Yadin, Masada: Herod's Fortress and the Zealot's Last Stand (New York: Random House, 1966).

4 See Kirsopp Lake, "Appendix A: The Zealots," in The Beginnings of Christianity, ed. Kirsopp Lake and Frederick J. Foakes-Jackson (London: Macmillan, 1920), 421-46; Solomon Zeitlin, "Zealots and Sicarii," JBL 81 (1962): 395-98; Zeitlin, “The Sicarii and Masada," JQR 57 (1967): 251-70; Morton Smith, "Zealots and Sicarii: Their Origins and Relation," HTR 64 (1971): 1-19; Richard A. Horsley, "The Zealots: Their Origin, Relationships and Importance in the Jewish Revolt," NovT 28 (1986): 159-92.

5 See among others, Trude Weiss-Rosmarin, "Masada and Yavneh," Jewish Spectator $3^{1}$ (1966): 4-7; Sidney B. Hoenig, “The Sicarii in Masada: Glory or Infamy," Tradition 11 (1970): 5-30; Valentin Nikiprowetzky, "La mort d'Eléazar fils de Jaïre et les courants apologétiques dans De Bello Judaico de Flavius Josèphe," in Hommages à André Dupont-Sommer, ed. André Caquot and Marc Philonenko (Paris: Maisonneuve, 1971), 461-9o; Louis H. Feldman, "Masada: A Critique of Recent Scholarship," in Christianity, Judaism and Other Greco-Roman Cults, Studies for Morton Smith at Sixty, Part 3: Judaism Before 7o, ed. Jacob Neusner, SJLA 12 (Leiden: Brill, 1975), 218-48; David J. Ladouceur, "Masada: A Consideration of the Literary Evidence," GRBS 21 (1980): 245-60; Shaye J.D. Cohen, "Masada: Literary Tradition, Archaeological Remains, and the Credibility of Josephus," JJs 033 (1982): 385-405; Ladouceur, "Josephus and Masada," in Josephus, Judaism, and Christianity, ed. Louis H. Feldman and Gohei Hata (Detroit: Wayne State University Press, 1987), 95-113; Raymond R. Newell, "The Forms and Historical Value of Josephus' Suicide Accounts," in Josephus, the Bible, and History, ed. Louis H. Feldman and Gohei Hata (Detroit: Wayne State University Press, 1989), 278-94; Jonathan P. Roth, "The Length of the Siege of Masada," Scripta Classica Israelica 14 (1995): 87-110; Israel Shatzman, "The Roman Siege of Masada," in The Story of Masada: Discoveries from the Excavation, ed. Gila Hurvitz (Provo: BYU Studies, 1997), 105-20; Kenneth Atkinson, 
narrative, which is a product of an ancient literate author, writing for an educated audience.

To gain insight into War's sicarii, this article will go beyond the Masada episode with an inquiry into all references to sicarii throughout Josephus's texts from the perspective of Greco-Roman rhetoric. This perspective is promising because various textbooks have survived, enabling the identification and evaluation of rhetorical devices and techniques in literary texts. ${ }^{6}$ Although the impact of Greco-Roman rhetoric on Josephus's texts in general has been much studied, ${ }^{7}$ the rhetorical function of the sicarii has only been recently addressed by Mason and Brighton. ${ }^{8}$ Their main conclusions overlap: the name sicarii is

"Noble Deaths at Gamla and Masada? A Critical Assessment of Josephus' Accounts of Jewish Resistance in Light of Archaeological Discoveries," in Making History:Josephus and Historical Method, ed. Zuleika Rodgers, JSJSup 110 (Leiden: Brill, 2007), 349-71; Nicolas Wiater, "Reading the Jewish War: Narrative Technique and Historical Interpretation in Josephus's Bellum Judaicum," MD 64 (2010): 145-86; Jodi Magness, "A Reconsideration of Josephus' Testimony About Masada," in The Jewish Revolt against Rome: Interdisciplinary Perspectives, ed. Mladen Popović, JSJSup 154 (Leiden: Brill, 2011), 343-6o.

6 I will limit this identification to the devices and techniques that are attested in texts which were potentially available in first-century Rome. Among these, I list Aristotle's Rhetoric (fourth century ВСЕ), Rhetorica ad Herennium (first century BCE), Cicero's De inventione rhetorica, De oratore (first century BCE) and Quintilian's Institutio oratoria (first century CE). The latter is a text which is published after War, but Quintilian was already active in Rome as a teacher of rhetoric under Vespasian at the time when Josephus wrote War; cf. Suetonius, Vesp. 18. and Jerome, Chron. 190 (Helm), and thus a valuable source for contemporary rhetorical theory and practice in Rome. An indispensable scholarly point of reference has been Heinrich Lausberg et al., Handbook of Literary Rhetoric: A Foundation for Literary Study (Leiden: Brill, 1998). I am also indebted to the overviews offered by G.O. Burton, "Silva Rhetoricae," http://rhetoric.byu.edu; Laurent Pernot, La Rhétorique dans l'Antiquité (Paris: Le Livre de Poche, 2000) and Thomas N. Habinek, Ancient Rhetoric and Oratory (Oxford: Blackwell, 2005).

7 For general assessments, see, e.g., Harold W. Attridge, "Josephus and His Works," in Jewish Writings of the Second Temple Period:Apocrypha, Pseudepigrapha, Qumran Sectarian Writings, Philo, Josephus, ed. Michael E. Stone, CRINT 2 (Assen: Van Gorcum, 1984), 157-232; Pere Villalba i Varneda, The Historical Method of Josephus, ALGHJ 19 (Leiden: Brill, 1986); Tamar Landau, Out-Heroding Herod:Josephus, Rhetoric, and the Herod Narratives, AJEC 63 (Leiden: Brill, 2006); Gottfried Mader, Josephus and the Politics of Historiography: Apologetic and Impression Management in the Bellum Judaicum, MnemosyneSup 205 (Leiden: Brill, 2000); Steve Mason, Josephus and the New Testament (Peabody: Hendrickson, 1992).

8 Steve Mason, Flavius Josephus: Translation and Commentary, Volume 1 B: Judean War 2 (Leiden: Brill, 2008), n. 1604 (FJTC, 1b); Mark A. Brighton, The Sicarii in Josephus's Judean War: Rhetorical Analysis and Historical Observations, EJL 27 (Atlanta: Society of Biblical Literature, 2009). 
derived from a Roman legal term and War's Roman audience must have known its primary meaning of "assassins." The application of the term in War is thus best understood as a rhetorical label similar to that of "bandits," "revolutionaries," and "partisans" among others. Josephus has adopted the label, so Brighton explains, to support some of War's major themes.

In the first place, the present study adds to the insights of Mason and Brighton. In the second place, it responds to renewed attempts to identify the sicarii as a unified rebel group, because such a construct fails to integrate these latest insights. ${ }^{9}$ More precisely, Brighton and Mason have pointed out that Josephus's use of the term sicarii is "somewhat fluid," showing "a degree of slippage."10 The term seems to refer to different groups, comprising a variety of actions between which there is no logical connection. As Mason summarises:

Certain sicarii, still carrying this name that Josephus connects with a technique for urban assassination (not with an ideology), will go to Masada under Eleazar's leadership (4.400, 516; 7.253-311); yet after the reportedly complete self-destruction of the group there, a substantial number of sicarii (600-1,00o?) escape to Alexandria from somewhere to cause further trouble (7.410-419). Yet again, after they have been removed to a man (7.416), "the madness of the sicarii" reappears in Cyrene-in the odd form of a general trouble-maker (not apparently an urban dagger-assassin) named Jonathan (7.437-444; for analysis, Brighton 2005: esp. 194-201). Even in the present passage, Josephus describes former friends using concealed knives to eliminate each other as part of the same social problem $(2.254,255-256)$ : this does not sound like a political or militant organization, but only a means of killing; the label sicarii seems to lack content. ${ }^{11}$

Most problematic is the connection between the sicarii of Masada and those in Alexandria and Cyrene, which is only made by the author's remark that the latter two originated from a "fled faction" of sicarii, despite his claim that the whole group of Masada was dead. Furthermore, an understanding of the term sicarii merely as a rhetorical label for assassins or a means of killing is also problematic since the groups labelled as such in War are not the only ones to commit murders. Why then does Josephus use the label in certain

9 E.g., Uriel Rappaport, "Who Were the Sicarii?" in Popović, Jewish Revolt against Rome, 323-42.

10 Resp. Brighton, Sicarii, xiii; Mason, FJTC, 1b, n. 1604.

11 Mason, FJTC, 1b, n. 1604. 
cases (and not others)?12 Furthermore, some actors labelled sicarii do not actually murder, like Jonathan of Cyrene. Is Josephus then inconsistent in his use of the term sicarii? Or, should we conclude that the term simply lacks content as Mason suggests? Such considerations indicate the limitations of our understanding of War's sicarii. ${ }^{13}$

Throughout this paper, I shall argue that Josephus's habit of labelling groups sicarii can be understood as an accurate allusion to a Roman law, which was used as a rhetorical commonplace in function of vituperation against specific groups. Rhetorical theories introduced the concept of vituperation, as opposed to praise, under the heading of the demonstrative genre of speech, in order to develop guidelines for "displaying" vices (or virtues) in denouncing (or praising) particular persons. ${ }^{14}$ In doing so, rhetoricians also collected common set pieces and arguments, called commonplaces. ${ }^{15}$ Studying War's sicarii from this perspective can thus offer insights into the meaning of the term, its function in the text and the intention of the author. I shall begin by exploring the possible

12 Josephus could consistently have called all murderers throughout his texts sicarii or have

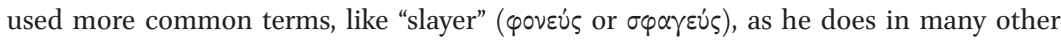
occasions, see, e.g., Josephus, J.W. 1.230, 331, 581; Ant. 1.57; 7.50; 9.68; 10.48; 14.280; 16.9, 72, 277; and Ant. 19.122, 158, 215, 252, 255, 261, 267.

13 Some credit belongs to Dmitry Braktin, who first identified a gap in Brighton's study: "[t]he only point I would like to criticize is the section on the meaning of the word sicarius / бixápıos. I feel that something is missing here, as sicarius is not merely a word in Josephus to be studied, but a legal concept with its own particular origin, the statute by which it was introduced (Lex Cornelia de sicariis et veneficiis), and development, not to mention that the issue was itself part of the legal concept of homicidium"; see Dmitry Braktin, review of The Sicarii in Josephus's Judean War: Rhetorical Analysis and Historical Observations, by Mark A. Brighton, Bryn Mawr Classical Review, 27 September 2010, http:// bmcr.brynmawr.edu/2010/2010-09-47.html.

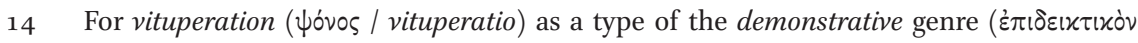

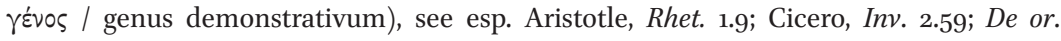
2.84.340-2.85.349; Quintilian, Inst. 3.7.

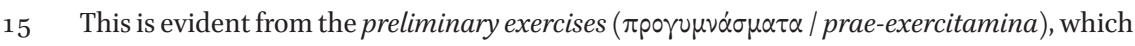
included an exercise in "commonplace" (xovvós có students in amplifying the virtues or vices of abstract, stereotypical subjects, such as a tyrant, as well as from the exercise in encomium and vituperation in which students have to praise or denounce a particular person. Although the first-century CE dating of the earliest treatise on preliminary exercises by Theon is contested, the practice probably already existed in the fourth century вСЕ, since it is mentioned in Rhetorica ad Alexandrum. See George A. Kennedy, Progymnasmata: Greek Textbooks of Prose Composition and Rhetoric (Atlanta: Society of Biblical Literature, 2003), x-xii; Malcolm Heath, "Theon and the History of the Progymnasmata," GRBS 43 (2002): 129-6o. 
meaning(s) which the term sicarius evoked among War's historical audience. Then, I shall analyse each reference to sicarii in War, as well as in Antiquities, in the light of this meaning, and identify the used commonplaces and other relevant rhetorical techniques. Finally, I shall reflect on the intention of the author by highlighting the relation between War's sicarii and three literary-rhetorical tendencies in the text of War as a whole.

\section{Audience and Meaning: Those Called sicarii in Rome}

Different elements in the text of War indicate that its author intended to write for a Roman audience that was educated in Greek, including Judeans living in

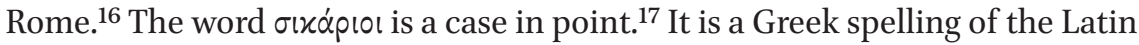
word sicarii, which literally means "sica-wielders" or, more accurately, "skilled users of the sica-type dagger." ${ }^{18}$ The loanword is not attested in any other Greek text contemporary to War-except for Acts 21:38, which probably paraphrases

16 For an assessment of War's audience, see Steve Mason, "Of Audience and Meaning: Reading Josephus's Bellum Judaicum in the Context of Flavian Audience," in Josephus and Jewish History in Flavian Rome and Beyond, ed. Joseph Sievers and Gaia Lembi, JSJSup 104 (Leiden: Brill, 2005), 71-100.

17 A classical view argues that the label sicarii in War is the authentic name of a Judean rebel movement and explains the Roman legal origin of the term as an appropriated "honorary title," see Martin Hengel, The Zealots: Investigations into the Jewish Freedom Movement in the Periode from Herod I until 7o AD (Edinburgh: T\&T Clark, 1989), 49. There is no support for this hypothesis in Josephus's texts. Only one phrase in Antiquities might suggest

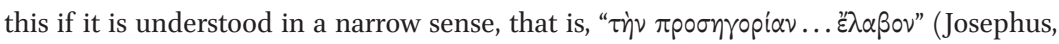
Ant. 20.186), which can be translated as the sicarii "took the name for themselves" - as Brighton does in considering Hengel's explanation, see Brighton, Sicarii, 57 and 144. However, it is preferable to translate "है $\lambda \alpha \beta$ ○" more generally here, as Thackeray (LCL) does. See also Rappaport, "Who Were the Sicarii?" 328. In such a reading, the passage means that these sicarii received that "appellation" ( $\pi$ po $\eta \gamma$ roi $\alpha$ ) because of their actions, which is in line with the vituperative rhetoric in the characterisation of War's sicarii, as I will argue throughout this paper.

18 For Latinisms in the texts of Josephus, see Joel S. Ward, "Roman Greek: Latinisms in the Greek of Flavius Josephus," CLQ 57 (2007): 632-49. I add the notion of "skilled" because other masculine substantives ending with -arius in Latin often refer to persons engaged in a certain skill, e.g., horrearius, librarius, or marmorarius. Compare the description of the methods of War's sicarii as a $\tau \dot{\varepsilon} \chi \nu \eta$ at Josephus, J.W. 2.257. See also Duncan Cloud, "Leges de sicariis: The First Chapter of Sulla's lex de sicariis," zsS 126 (2009): 114-55, esp. 117. 
War. ${ }^{19}$ It might be an original Josephan borrowing. This explain why Josephus so often guides his audience with prefixes, such as "so-called" sicarii, and a basic definition of the term, namely a "kind of bandits who carry daggers under their clothes," and why he compares the sica-dagger with the Persian acinaces (or scimitar) in Antiquities (20.185-186) in order to clarify this Roman term to a Greek or Judean part of his audience in Rome. ${ }^{20}$ With such guidance, however, an informed Roman audience could easily recognise War's sicarii as referring to the famous lex Cornelia de sicariis (et veneficiis), hereafter Lex de sicariis.

Although scholars often refer to this law as Sulla's "murder law," "murderer" does not cover the legal category of sicarius accurately. The law was introduced in the aftermath of the Roman civil wars as an integral part of Sulla's reforms (ca. $81 \mathrm{BCE}$ ) to defuse public violence, rather than to prosecute occasional murderers. ${ }^{21}$ Furthermore, someone brought before the quaestio inter sicarios was not necessarily a murderer. ${ }^{22}$ This is evident from the four legal clauses of the Lex de sicariis, which are attested in a quote by the jurist Aelius Marcian in the Digest:

[S]omeone is liable [1] who kills any man or [2] by whose malicious intent a fire is set; or [3] who goes about with a weapon for the purpose of [3.a] homicide or [3.b] a theft; or [4] who, being a magistrate or presiding over a criminal trial, arranged for someone to give false evidence so that an innocent man may be entrapped [and] condemned. (Dig. 48.8.1 [transl. Watson, 1985])

19 The passage mistakenly confuses War's sicarii with the so-called "Egyptian pseudoprophet"; see Mason, Josephus and the New Testament, 210-13. Another possibility is that the author of Acts was informed of the legal meaning of the term and thus understood the followers of the "Egyptian" to be liable of being sicarii as well, since the Egyptian

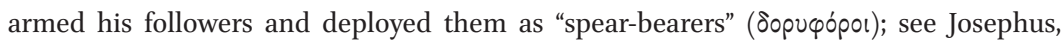
J.W. 2.261-263.

20 Cf. Justinian, Inst. 4.18.5: “'Sicarius,' or assassin, is derived from 'sica,' a long steel knife”

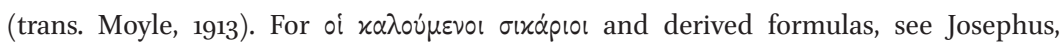
J.W. 2.254, 425; 4.400; Ant. 20.186. For basic definitions, see Josephus, J.W. 2.254, 425; Ant. 20.164 and 186. For a comparison between the sica and Persian scimitar, see Ant. 20.186. See also Brighton, Sicarii, 58 .

21 See Duncan Cloud, "The Primary Purpose of the lex Cornelia de sicariis," zss 86 (1969): 258-86; Jean-Louis Ferrary, "Lex Cornelia de sicariis et veneficiis," Athenaeum 69 (1991): 417-34; Cloud, "Leges de sicariis," 114-55.

22 Cf. Cicero, Inv. 59-6o, see Judy E. Gaughan, Murder Was Not a Crime: Homicide and Power in the Roman Republic (Austin: University of Texas Press, 2010), 72-77, esp. 74. 
Although a sicarius is commonly associated with the offence of homicide (cf. Justinian, Inst. 4.18.5), Marcian's note also connects with the offence of arson, illegal carrying of weapons, theft, and false testimony. ${ }^{23}$ In what follows, I will demonstrate that Josephus alludes to each of these crimes in War's narratives on sicarii, but before we continue, it is important to draw attention to three aspects.

Firstly, Roman law was accumulative and subject to processes of alteration. This makes it difficult to verify whether the quote of Marcian, which is written in the third century CE and transcribed in the Digest in $533 \mathrm{CE}$, attests the original law. The Digest is a compilation that is part of emperor Justinian's codification of Roman law, commonly referred to as the Corpus iuris civilis. ${ }^{24}$ The preface of the Digest includes the instructions given to a commission of experts, which is to collect the works of authoritative Roman jurists into a single work ( C. Deo auctore 4). This resulted in a fifty-volume work that is comprised of titles with headings under which excerpts were grouped. A note ascribed each excerpt to the source from which these were taken. Accordingly, Marcian's quote was taken from "Marcian, Institutes, book 14" and it is the first excerpt that is found under the eighth title Ad legem corneliam de siccariis et veneficis in book 48 (covering public law), after which other excerpts follow. Despite such ascriptions, it is not safe to assume that the quote is a copy of what Marcian actually wrote in the third century $\mathrm{CE}$, because the compilers were also instructed to omit, simplify, add, correct, alter, rearrange, and restyle the citations to avoid repetition and to eliminate contradictions (C. Deo auctore $7-9)$. The criteria by which these compilers made interpolations remain unclear, ${ }^{25}$ but that there

23 It is noteworthy that three of these crimes could also evoke the Decalogue among War's Judean audience (i.e., "you will not kill," "you will not steal," and "you will not bear false witness"), see Exod 20:14-8, Deut 5:17-20; cf. Philo, Dec. $5^{1}$ and Josephus, Ant. 3.92. This has the potential of successful invective not only in terms of Roman law, but also Judean law.

24 The other parts are the Institutes, the Code, and the later Novels.

25 Franz Wieacker, Einleitung, Quellenkunde, Frühzeit und Republik, vol. 1 of Römische Rechtsgeschichte: Quellenkunde, Rechtsbildung, Jurisprudenz und Rechtsliteratur (Munich: Beck, 1988), 154-82; David Johnson, “Justinian's Digest: The Interpretation of Interpolation," Oxford Journal of Legal Studies 9 (1989): 149-66; Tony Honoré, "Some Suggestions for the Study of Interpolations," Tijdschrift voor Rechtsgeschiedenis 49 (1981): 225-49; Alan Watson, "Prolegomena to Establishing Pre-Justinianic Texts," Tijdschrift voor Rechtsgeschiedenis 62 (1994): 113-225. A recent state of research can be found in Tony Honoré, Justinian's Digest: Character and Compilation (Oxford: Oxford University Press, 2010). 
were (silent) interpolations is undisputed. ${ }^{26}$ On the other hand, the commission also claims that the original texts were handled with great respect (C. Deo auctore 7 ; Tanta 10). Fortunately, there are some independent attestations of the Lex de sicariis. There is an older citation by Ulpian, who wrote in the first part of the third century $\mathrm{CE}$, which attests three of Marcian's clauses, including the offence of killing, illegal carrying of weapons, and theft (Ulpian, Col. 1.3.1). ${ }^{27}$ There are also different indirect references in the texts of Cicero, which attest the offences of arson and bribery of magistrates, besides those of killing and the illegal carrying of weapons. ${ }^{28}$ Altogether, the evidence is rather limited and insufficient for historical reconstructions of the original lex de sicariis or the version which Josephus might have referred to when he wrote his text in the first century CE. The objective of this paper is therefore limited to the offering of a heuristic tool: the attested content of the lex de sicariis helps to understand Josephus's presentation of sicarii in War.

Secondly, it is unlikely that Josephus expected that everyone among War's audience knew the lex de sicariis in detail. He most likely alludes to the different clauses of the law in order to make his vituperative accusations plausible and most effective, that is, to be sure that even an informed audience would agree that those whom he labels sicarii can be accused of being such criminals (cf. Cic. Top. 19.73-74). A good example of this kind of applications of the

26 One example is a case claiming that provincial governors could not act concerning the lex Julia de maiestate "without the instruction of the principes" (D. 48.4.3). This can only be explained as a silent modification (most likely by Marcian) of its original "without the instruction of the senate and Roman people"; see also John Matthews, "Roman Law and Roman History," in A Companion to the Roman Empire, ed. David S. Potter (Malden, MA: Blackwell, 2010), 477-91, esp. 490.

27 I quote: "anyone who has gone about with a weapon [cf. cl. 3 of Marc. cit.] for the purpose of committing murder [cf. cl. 3.a] or theft [cf. cl. 3.b], or has slain a man [cf. cl. 1], or has wilfully caused this offence to be committed [cf. cl. 4]" (trans. Hyamson 1913). There are thus three deviations. Firstly, the order of the clauses of "killing someone" is different. This is perhaps a later rearrangement, since manslaughter was the primary purpose of the law at the time of Marcian; see Gaughan, Murder Was Not a Crime, 75-76; compare Cicero, Parad. 31 with Ulpian, coll. 1.3.1, see Cloud, "Primary Purpose," 265-67. Secondly, the fourth clause is more specific in Marcian's quote. Thirdly, and most importantly, the act of arson is absent in Ulpian. This can be explained as an omission by Ulpian or a later amendment.

28 See Cicero, Rab. Perd. 19 (confiteor interficiendi Saturnini causa C. Rabirium arma cepisse); Mil. 11 (ipsa lex potestatem defendendi, quae non hominem occidi, sed esse cum telo hominis occidendi causa vetat); Parad. 31 (qui incendium fecerit); and Clu. 144-157, esp. 155 (i.e., ne quis iudicio circumveniretur); see also Cicero, Parad. 31 (see discussion below). 
lex de sicariis in vituperative speech can be found in Cicero's Stoic Paradoxes, which prepares six controversial philosophical postulates as rhetorical commonplaces for practical use in judicial cases (Parad.1-5). Under the heading of "every foolish man is mad" (Parad. 27-32), Cicero characterises an imaginary interlocutor (who can be identified as Clodius) as the leader of "plunderers" (praedones) and "bandits" (latrones) in the wake of Catiline's conspiracy and he accuses him of the following crimes:

You caused a massacre in the forum, you held the temples with armed brigands, you burnt private persons' houses and consecrated buildings. (Cicero, Parad. 30 [Rackham, LCL])

In proving these accusations, Cicero cites three clauses taken from the lex de sicariis:

'A person found with a weapon' [i.e., cl. 3]: your dagger [i.e., sica] was detected in front of the senate-house; 'who has killed a man' [i.e., cl. 1]:you have killed a great many; 'who has caused a fire' [i.e., cl. 2]: your hand set fire to the Temple of the Nymphs and it was burnt down; 'who has seized temples': you encamped in the forum. (Cicero, Parad.31 [Rackham, LCL])

It was common to cite laws in a judicial argument, as Cicero does here, but in narrative texts, such as War, this would be bad style. Therefore, it is only to be expected that Josephus limits his references to discursive markers (i.e., socalled sicarii) and allusions in the hope that his audience had sufficient prior knowledge to make the link.

Thirdly and closely related, it is important to note that legal concepts such as sicarii and "bandits" ( $\lambda \eta \tau^{\prime} \alpha i$ / latrones) were often flexibly applied by rhetoricians and that this affected general understandings of the law. ${ }^{29}$ For example, the Digest states that all violators who are not officially in a state of war are "bandits" and "plunderers" (Dig. 50.16.118). Such a definition allows the legal category of "bandit" to be used as a weapon of accusation against political rivals if the rhetorician could prove that the opponent used illegal means in political conflicts, which is often the case in violent civil wars that failed

29 See George A. Kennedy, A New History of Classical Rhetoric (Princeton: Princeton University Press, 1994), 115; Johannes Stroux, Römische Rechtswissenschaft und Rhetorik (Potsdam: Stichnote, 1949); John A. Crook, Legal Advocacy in the Roman World (London: Duckworth, 1995); Olga Tellegen-Couperus, "Roman Law and Rhetoric," RBPH 84 (2006): 59-75. 
to be presented as a bellum iustum. ${ }^{30}$ This is the strategy of Cicero's famous orations in which he characterises Catiline, a political rival, as a villainous "gangster" (i.e., latronus) who "conspires" against the res publica. ${ }^{31}$ The same tendency is present in the texts of Josephus, who deploys the label "gangster" ( $\lambda \eta \sigma \tau \dot{\eta} \varsigma)$ to discredit politically motivated usurpers, including his arch-rival John of Gischala. ${ }^{32}$ Accusations of crimen inter sicarios can be applied in the same way. Clodius accused Milo, for example, of being a "bandit and assassin" (latronem ac sicarium) who acted on Cicero's orders (Cicero, Mil. 18), while Cicero himself also consistently connects the concept of sicarii with "conspiracies," "planning," and "concealment" throughout his speeches. ${ }^{33}$ Accordingly, Josephus describes the sicarii as "crafty in eluding detection" (J.W. 2.257) and their actions as "plots" (7.441).

Because of such tendencies, it is necessary to distinguish between two levels of meaning for concepts such as "bandits" and sicarii. On the one hand, the term "bandit" can have a legal meaning, which is a violator who takes recourse to illegitimate means of politics and, on the other hand, the term can have a more general negative connotation of villainous "gangster." For the sicarii, whom Josephus first introduces as "a new kind of bandits" (J.W. 2.254), there is then a legal meaning of a new form of illegitimate politics, which is specified by crimen inter sicarios, and a more general negative connotation of villainous "knifers" or "cut-throats." 34 Although a good rhetorical accusation succeeds

$30 \quad$ See esp. Brent D. Shaw, "Bandits in the Roman Empire," Past and Present 105 (1984): 3-52, esp. 21-23.

31 See, e.g., Cicero, Cat. 1.1-2, 31-3, 2.24, etc. See also T.N. Habinek, The Politics of Latin Literature: Writing, Identity, and Empire in Ancient Rome (Princeton: Princeton University Press, 2001), 69-87.

32 See Thomas Grünewald, Bandits in the Roman Empire: Myth and Reality (London: Routledge, 2004), 91-109, esp. 100. Compare the career of John of Gischala, who was a man of considerable political weight during the revolt, see Uriel Rappaport, "John of Gischala: From Galilee to Jerusalem," JJs 33 (1982): 479-93; Rappaport, "John of Gischala in Galilee," in The Jerusalem Cathedra: Studies in the History, Archaeology, Geography and Ethnography of the Land of Israel, vol. 3, ed. Lee I. Levine (Jerusalem: Yad Izhak Ben-Zvi Institute, 1983): 46-57.

33 See Cloud, "Leges de sicariis," 114-55.

34 Cloud observes that both Cicero and Josephus use the term as an equivalent of a "gangster" ( $\lambda \eta \sigma \tau$ ' $/$ / latro), who is "part of a societas" and who "kills or arranges killings for financial gain"; see Cloud, "Primary Purpose," 273. Despite his conclusion that Josephus uses the term almost identically as Cicero does, Cloud unfortunately adds that there is a major difference between Josephus's use of the term, which is the intense patriotism of the sicarii; see ibid., 281-83. In this way, Cloud connects with the scholarly consensus of that time, which saw the sicarii as an anti-Roman rebel movement. 
both in proving that the accused is legally liable and in characterising him as a villain, the distinction is crucial to explore the grey zone in between these two meanings, especially when we consider the rhetorical device of "improper use of a word." Quintilian illustrates this device exactly with the praxis to "call everyone who murders with any weapon a 'knifer' [i.e., sicarius]" (Inst. 10.1.12 [Goold, LCL] $).{ }^{35}$ It is perfectly possible that War's rhetoric on sicarii applies this device, and that hence the concept loses its legal meaning or lacks content, as Mason suggests, but a close reading of each reference to sicarii in War with respect to the lex de sicariis concludes that Josephus alludes to its clauses in a rather accurate way.

Overall, there are fifteen occurrences of sicarii in Josephus's Judean War in the context of five distinct narrative units and four occurrences in his Antiquities that are part of a single narrative unit, which overlaps the first narrative of War's account. ${ }^{36}$

J.W. 2.254-257 and Ant. 20.160-165: Villainous Assassins in Jerusalem before the Revolt

The exposition of War's sicarii, which is found in book 2 of War, includes the basic legal concept of a sicarius, as well as different rhetorical commonplaces:

The so-called sicarii ... committed murders in broad daylight in the heart of the city. The festivals were their special seasons, when they would mingle with the crowd, carrying short daggers concealed under their clothing, with which they stabbed their enemies. Then, when they fell, the murderers joined in the cries of indignation and, through this plausible behaviour, were never discovered. The first to be assassinated by them was Jonathan the high priest; after his death there were numerous daily murders. (Josephus, J.W. 2.254-257 [Thackeray, LCL])

The act of "carrying daggers concealed under clothing" both connects with secrecy and conspiracy and presents a crimen inter sicarios, namely illegal carrying of weapons (cl. 3) for the purpose of murder (cl. 3.b) in which they

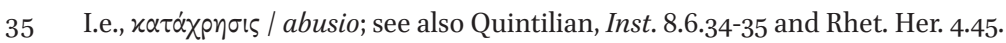

36 See Josephus, J.W. 2.254, 425; 4.400, 516; 7.253, 254, 262, 275, 297, 311, 410, 412, 415, 437, 444; Ant. 20.186, 204, 208, 210. 
succeed (cl. 1). In addition, the claims that these sicarii murdered "in broad daylight in the heart of the city," being the temple, and that the holy "festivals were their special seasons" are not neutral settings of place and time, but share out denunciation. ${ }^{37}$ As Quintilian illustrates, "you have stolen private money, but as it was from a temple, this is sacrilege, not theft" (Inst. 5.10.39 [Goold, LCL]). This accusation of sacrilege is explicitly articulated in the account of the assassination of Jonathan in Antiquities:

These gangsters ... committed these murders not only in other parts of the city but even in some cases in the temple; for there too they made bold to slaughter their victims, for they did not regard even this as a desecration. This is the reason why, in my opinion, even God Himself, for loathing of their impiety, turned away from our city and, because He deemed the temple to be no longer a clean dwelling place for Him, brought the Romans upon us and purification by fire upon the city, while He inflicted slavery upon us together with our wives and children; for He wished to chasten us by these calamities. (Josephus, Ant. 20.163-165 [Feldman, LCL])

Subsequently, War's account describes the effects of the actions of the sicarii: potential victims became "suspicious" and "on their guard" against their "(distinguished) opponents" and lost "trust" in their "friends" (J.W. 2.257). ${ }^{38}$ This is exactly the sort of crisis in political relations which the lex de sicariis

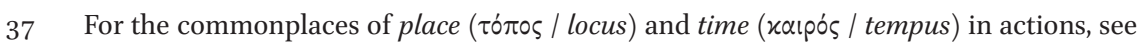
esp. Quintilian, Inst. 3.6.25-26.

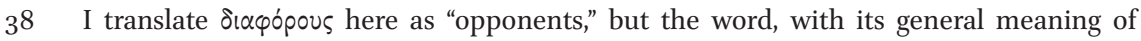
"distinct," could also evoke the meaning of "elites." Mason suggests that the repetition

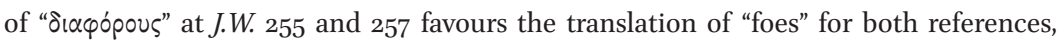
because this translation is evident for the later one; see Mason, FJTC, 1b, n. 1608 and 1617. However, War's audience does not receive the text from end to beginning. A double meaning of "distinguished [men]" and "opponents" in relation with the term sicarii and theme of the assassination of a high priest is a more natural association. If conscious,

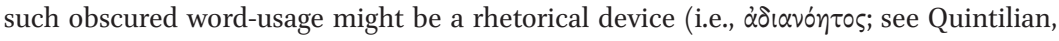
Inst. 8.2.20) enabling both an obvious understanding (i.e., the elite is under attack) and a deeper understanding (i.e., the elite is under attack by itself). The latter would hint at a more complex reality than the picture of a Judean leadership caught between opposing forces as War's narrator often implies. However, being too explicit on elite factionalism could potentially expose the Judean priestly elite, including Josephus himself, to blame. 
aimed to avert, ${ }^{39}$ and which the author presents as disastrous probably for the same reason as Cicero remarks on trust among friends: "one who violates this promise attacks what is the common safeguard of all, and, as far as it is in his power, ruins all social life" (Rosc. com. 111 [Freese, LCL]). Accordingly, Josephus comments that "the panic created was more alarming than the calamity itself," since "everyone" among the Judean leaders could expect to be attacked himself, after which he fittingly adds the simile "as on the battlefield." In this way, the passage should be understood both as a denunciation of sicarii crimes in Judean politics and a metonymic description of violent factionalism. ${ }^{40}$

The function of this rhetoric on sicarii becomes clear when the immediate narrative context is considered. The first reference to sicarii is part of a list of four dramatis personae which affects rhetorical amplification and climax, ${ }^{41}$ implying that the one outdoes the other in the severity of their crimes in a context of increasing political corruption: first, there was Eleazar the "banditchief," who ravaged the country, but "while the country was thus cleared of these pests, a new kind of bandits was springing up in Jerusalem," who were sicarii; then, "there arose another body of villains, with purer hands but more

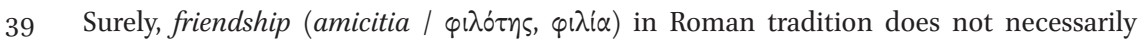
refer to political relations; see, e.g., Peter A. Brunt, "Amicitia in the Roman Republic," in The Fall of the Roman Republic and Related Essays, ed. Brunt (Oxford: Clarendon

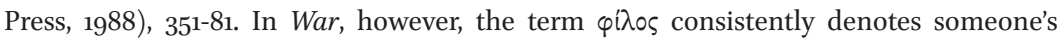
political advisor or supporter; see, e.g., 1.49, 113, 280-281, 340, 361, 390-394, 571-577; 2.21, 68-69, 81-82, 104, 6oo; 3.195; 4.223, 252; 5.326, 476; 6.324, 412; 7.26, 327. See also Mason, FJTC, 1b, n. 488. Furthermore, the term "íróvol $\alpha$," which is also in this passage, has parallel usages in the context of betrayal in aristocratic circles; see, e.g., Josephus, Ant. 2.256. For discourse on conspiracies, see, e.g., Victoria E. Pagan, Conspiracy Narratives in Roman History (Austin: University of Texas Press, 2004), esp. 10-14; Joseph Roisman, The Rhetoric of Conspiracy in Ancient Athens (Berkeley and Los Angeles: University of California Press, 2006), esp. 2-6.

$40 \quad$ I.e. "talking around" a subject ( $\pi \varepsilon p i \varphi p \alpha \sigma \iota \varsigma /$ circumlocutio) by using the trope of metonymy ( $\mu \varepsilon \tau \omega \nu \nu \mu i \alpha /$ transmutatio, transnominatio), see Rhet. Her. 4.32.43 and Quintilian, Inst. 8.6.23-27; Rhet. Her. 4.32.43 and Quintilian, Inst. 8.6.29-30.

41 For amplification ( $\alpha$ ü ${ }_{\eta} \sigma \varsigma \varsigma$ / amplificatio), see Aristotle, Rhet. 1.9.40 and Cicero, De or. 3.26.104-127.105. Amplification is an important rhetorical tool which can be defined as follows: "[it] denotes the enlargement of a proposition or, more generally, the extension of a text by the multiplication and variation of its constituents... in order to heighten the rhetorical effect... constituents such as subject matter,... action,... character,... genre.... Amplification is achieved by dividing a statement into its parts or splitting up a whole into concrete phenomena"; see Heinrich F. Plett, "Amplification," in Encyclopedia of Rhetoric, ed. Thomas O. Sloane (Oxford: Oxford University Press, 2001), 25-26. For climax, see Rhet. Her. 4.25. 
impious intentions," the so-called "deceivers and impostors," who showed divine "tokens of deliverance" to the people in the desert; and, finally, "an even worse blow was dealt at the Judeans by the Egyptian false prophet," who tried to overpower the Roman garrison of Jerusalem in order to "set himself up as a tyrant," employing his followers as his "bodyguard" (J.W. 2.253-263 [Thackeray, LCL]). Both the climactic amplification and the vituperative language resemble a list of six types of villains that is found in Cicero's speeches, which includes "bandits," sicarii, and Catiline's "especial selection" of thugs among others (Cat. 2.8.17-10.23, cf. 2.1.7). The latter ends the list as an encompassing symbol for Catiline's tyranny, which Cicero aimed to denounce. In War, this role is filled by the "Egyptian false prophet," a figure that combines the characteristics of its preceding colleague villains, especially the "bandits" and "deceivers," in a way that he is characterised as a political usurper and a "charlatan" who "tricks" people in the dessert, after which he even aspires "tyranny" by arming his followers as "bodyguard" - the latter being a commonplace in Greco-Roman literature (e.g., Polybius, Hist. 13.6.5). ${ }^{42}$ As such, this four-part list is intended to highlight particular vices in Judean politics in function of a general rhetorical strategy that is found in the narrative of War as a whole (see part 3, below).

The parallel account of Antiquities confirms such interpretations. It repeats War's four-part list of dramatis personae, including Eleazar son of Dinaeus and his "gangsters" (20.160-161); the assassins of Jonathan (162-165); the "impostors who deceived the mob" (160, 167-168); and the so-called Egyptian "prophet" (169-172). The passage on the assassination of Jonathan also implies political factionalism with the additional claims that a certain Doras, "one of Jonathan's most faithful friends," was bribed to betray Jonathan and that procurator Felix had authorised the murder (20.163). ${ }^{43}$ Josephus also adds that the assassins acted freely after the murder of Jonathan and "slew some because they were private enemies and others because they were paid to do so by someone else" $(20.163,165)$. Yet, despite such typical sicarii crimes and the repetition of the formula of "daggers concealed under their clothes" (at 20.164 and 165), the assassins are not labelled sicarii, but "gangsters." The first reference to

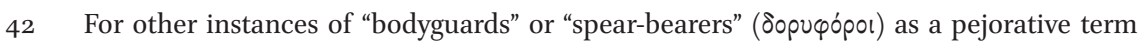
connected to tyrants in War, see $2.263,275,434$, and 564 among others. See also Mason, FJTC, 1b, n. 1653 .

43 "Bribery" is one of the seventeen frequently appearing loci for ad hominem invective in Greco-Roman rhetoric, as identified by Craig in comparative research; see Christopher P. Craig, “Audience Expectations, Invective, and Proof in Cicero's Judicial Speeches," in Cicero the Advocate, ed. Jonathan G.F. Powell and Jeremy Paterson (Oxford: Oxford University Press, 2004), 187-213, esp. 190-91. 
sicarii in Antiquities appears in the subsequent narrative on how procurator Festus dealt with a "large numbers of the gangsters" (20.185-188). Again, the passage repeats the basic characterisation of War's sicarii and then states that they "would also frequently appear with arms in the villages of their foes and would plunder and set them on fire" (20.187), referring to the sicarii crimes of carrying weapons (cl. 3) theft (cl. 3.b) and arson (cl. 2). The last reference to sicarii in Antiquities, however, does not include crimen inter sicarios. Rather, Josephus accuses the high priest Ananias of bribery and corruption, including putting pressure on Albinus to release captured sicarii in return for his abducted secretary (20.204-210). Compared to the passage in War, the rhetoric on sicarii is somewhat less rigorously deployed in Antiquities, but it is generally in line with the content of the lex de sicariis, while the added details of conspiracy, bribery, betrayal, and gangsterism serve to spice up the more elaborate stories of dirty politics, confirming the connection between the rhetoric on sicarii and the theme of political factionalism. ${ }^{44}$

\subsection{J.W. 2.425-429: Conspiring Promoters of War during the Outbreak of the Revolt}

The second reference to sicarii, which is also found in book 2 of War (425-429), is consistent in terms of allusions to the lex de sicariis and deployment of commonplaces for rhetorical vituperation. There is the formula "so they called the bandits who carried a sword in their bosom," that is, the offence of illegal carrying of weapons (cl. 3), and there is the accusation of sacrilege (in locus and tempus) in a way that these sicarii commit their crime on the temple square during a cultic feast. The weapons, however, are not "small daggers" for assassinations, but "swords" that are smuggled into the temple in order to arm rebels. ${ }^{45}$ This is significant because the passage is part of a larger narrative (409-456), which has a chronological causal sequence of events for describing a progress towards armed rebellion and violent faction struggle in Jerusalem. ${ }^{46}$ This

44 For a general evaluation of the inclusion of such narratives in Antiquities, see esp. James McLaren, "Corruption among the High Priesthood: A Matter of Perspective," in A Wandering Galilean: Essays in Honour of Sean Freyne, ed. Zuleika Rodgers, Margaret Daly-Denton, and Anne Fitzpatrick-McKinley, JSJSup 132 (Leiden: Brill, 2009), 141-58, esp. 146-51.

45 A $\xi i \varphi \circ \varsigma$ is a large size sword compared to the previously mentioned "small daggers" ( $\mu \iota x \rho \dot{\alpha}$ $\xi ı\left(\delta^{\prime} \iota \alpha\right)$; see also Mason, FJTC, 1b, n. 2679.

46 In defining this narrative unit, I considered the following five criteria proposed by Noël Carroll's; “(1) the discourse represents at least two events and/or states of affairs (2) in a globally forward-looking manner (3) concerning the career of at least one unified subject (4) where the temporal relations between the events and/or states of affairs are perspicuously ordered, and (5) where the earlier events in the sequence are at least 
narrative includes a complex of interacting rhetorical devices that explains why Josephus only applies the label sicarii once, despite the fact that he continuously refers to many sicarii crimes throughout the narrative, including the arming of rebels $(425,433-434)$, arson $(426,427,429,430,440)$, theft $(427,440)$ and killing (408, 440, 441, 445-446, 448, 450, 453, 456), which are committed by different groups.

An outline of the narrative content observes a first rhetorical device. It is a parallel with two parts (A, $\left.\mathrm{A}^{\prime}\right)$ that is achieved by introducing two key actors (who are in small caps), namely "Eleazar the temple captain" and "a certain Menahem" (409, 433), at two points in the narrative, together with a repetition of a temporal formula and a shift in narrative space (these are in bold). These introductions somewhat interrupt the narrative flow and are succeeded by a series of actions including allusions to sicarii crimes (that are put in italic): ${ }^{47}$

(A) "And now [ $\left.\alpha \dot{\alpha} \nu \tau \tau^{\prime} \tau \omega\right]$ " at Masada: "some of the most ardent promoters of hostilities banded together." They captured the fortress of Masada and "slew the Roman guards [cl. 1]." (2.408)

"At the same time" in Jerusalem, Eleazar the temple captain refused the sacrifices of foreigners, including those in honour of the emperor. An assembly discussed his decision, but Eleazar stood fast. The peace party appealed to Agrippa, who sent reinforcements. (2.409-424)

"Seven days" of street fights occurred between the peace and war factions among the Judeans. $(2.422-424)$

On "the eighth day," being "the feast of wood-carrying," some sicarii armed the rebels [cl. 3]. The royal troops retreated to Herod's palace, whereupon the rebels burned the palaces of Agrippa and Bernice [cl. 2], as well as the archives "to destroy the money-lender's bonds" and "cause a rising of the poor against the rich" [cl. 2, 3.b]. (2.425-429)

"On the next day," the rebels besieged the Antonia fortress, captured it and burned it [cl. 2]. They then turned to Herod's palace, but failed to capture it (2.430-432).

causally conditions for the causations of later events and/or states of affairs (or are contributions thereto)"; see Noël Carroll, "On the Narrative Connection," in Beyond Aesthetics: Philosophical Essays, ed. Carroll (Cambridge: Cambridge University Press, 2001), 118-33, esp. 126.

All translated quotes throughout this overview are taken—with minor adaptions and my emphasis-from Thackery, LCL. 
$\left(\mathrm{A}^{\prime}\right)$ "And now [ $\left.\varkappa \dot{\alpha} \nu \tau \tau^{\prime} \tau \omega\right]$ " at Masada: Menahem went to Masada and armed his followers [cl. 3]. (2.433-434)

"Then," Menahem "returned like a veritable king to Jerusalem and became the leader of the faction struggle and directed the siege of the palace [of Herod]." The rebels captured the palace, rushed "into the quarters just deserted by the soldiers, killed all the stragglers [cl. 1] whom they could lay hands on, rifled the baggage and set fire to the camp [cl. 2, 3.b]. These events took place on the sixth of the month Gorpiaeus." (2.434-440)

"On the following day the high-priest Ananias was caught ... and, with his brother Ezechias, was killed [cl. 1]," whereupon Menahem became a tyrant. (2.441-443)

"The partisans of Eleazar [the temple captain] now rose against him;... all who were caught were massacred [cl. 1].... Menahem himself, was caught, dragged into the open, and after being subjected to all kinds of torture, put to death [cl. 1]." (2.444-448)

Yet, "the conspirators, in killing Menahem [cl. 1], had no desire to end the war." So, despite a treaty which secured the safe retreat of the Roman garrison from Jerusalem, "Eleazar's party fell upon them, surrounded and massacred them [cl. 1];... on the Sabbath." $(2.449-456)$

This basic parallel also establishes an amplifying climactic structurecomparable to that of the four dramatis personae in the former passage on sicarii. Crucial in its development is the characterisation of Eleazar and Menahem, as well as the chain of events following their actions, in which there is an increase in vituperative speech based on commonplaces such as sicarii-crimes, but also banditry, tyranny, sophism, conspiracy, and sacrilege. Thus, Eleazar the temple captain is characterised as "a very daring youth" and identified as the son of Ananias, the officiating high-priest (409). This characterisation connects with the commonplace of "bold youths" versus "tempered elders," which is found throughout War and other Greco-Roman texts. ${ }^{48}$ Indeed, his decision to refuse the sacrifices of foreigners, including those in honour of the emperor, not only "laid the foundation of the war" $(2.409,418)$, but also of the factionalism among the Judeans: his decision was a "strange innovation"

48 See, e.g., Thucydides, Hist. 1.42 and Polybius, Hist. 2.21.2. See Mader, Josephus and the Politics of Historiography, 70-73; Arthur M. Eckstein, "Josephus and Polybius: A Reconsideration," Classical Antiquity 9 (1990): 175-208, esp. 192-94; and Mason, FJTC, 1b, n. 1409 . 
in Judean cult (cf. Judas's "innovative philosophy" below) that was reprimanded by the "priestly experts" and the "leading citizens" (411-418 [Thackeray, LCL]). The result was a schism between, on the one hand, "the leading men, the chief priests and all the people who were in favour of peace" and, on the other hand, "the insurgents," who confronted each other in street fights (419424). This stalemate only got broken when some sicarii managed to arm the rebels, initiating a military-like advance of the war faction in which they committed sicarii crimes by plundering and burning buildings. This advance, however, stagnated at Herod's palace, where the peace faction was hiding, including the high priest Ananias (425-432). It then takes a new actor to initiate further advances. This actor is Menahem. His introduction also connects with the Fourth Philosophy (see below), since he is identified as a "son of Judas surnamed the Galilean," a "sophist" who protested against Roman rule, and he is characterised as a "tyrant": Menahem arms "fellow-townsmen" and "other gangsters," deploying them as his "bodyguard," in order to enter Jerusalem "like a veritable king" (433-434), despite his ignoble background (443). ${ }^{49}$ This arming of rebels triggers a new series of sicarii crimes, including plunder, arson and - in addition to the former episode - the killing of opponents (440). Most significant is the murder of Ananias the high priest (441). Although the actual murderers are not identified, it is implied that it was Menahem's group, since they conducted the siege of Herod's palace and because "the murder of the high priest Ananias inflated and brutalized Menahem to such an extent that he believed himself without a rival in the conduct of affairs and became an insufferable tyrant" (442). ${ }^{50}$ This accusation of tyranny is confirmed by Menahem's act of showing up at the temple "in royal robes" with his "armed fanatics" (444). ${ }^{51}$ At this point, Eleazar, who is the son of the murdered high-priest, calls for action against Menahem: "Eleazar and his companions rushed upon him, and the rest of the people... took up stones and began pelting the arrogant sophist, imagining that his downfall would crush the whole faction struggle" (445). ${ }^{52}$ Menahem got caught and was killed (446-448). Ironically, Eleazar has now committed the same crime that made him act against Menahem, which reveals a tragic discovery: "The people ... co-operated in this plot in the hope of its producing some radical cure for the faction struggle; but the conspirators,

49 For these elements as commonplaces of tyrants, see above.

50 See also Brighton, Sicarii, 77 .

$5^{1}$ See also Josephus, J.W. 2.434. "Aspiring to regnum or tyranny" is a common locus for ad hominem invective in Greco-Roman rhetoric, see Craig, "Audience Expectations, Invective, and Proof in Cicero's Judicial Speeches," 190-91.

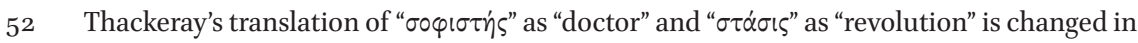
"sophist" and "faction struggle" to emphasis thematic coherences (see above and below). 
in killing Menahem, had no desire to end the war, but only to prosecute it at greater liberty" (449). ${ }^{53}$ Accordingly, Eleazar's party massacres the Roman garrison (453). The "moderates" now concluded that war with Rome was inevitable and that they would "suffer for the rebels' crime," since "the massacre took place on the Sabbath, a day on which from religious scruples Judeans abstain even from the most innocent acts" (455-456).

Another ordering device in this narrative is a seven-part chiasmus or ring structure (a, b, c, x, c', b', a'), which is a variant of parallelism that arranges content related parts in a symmetric, mirror-like way around a central axis in order to emphasise the first, central and last parts. ${ }^{54}$ Thus, the narrative begins with the killing of a Roman garrison at Masada ( $a$; 408) and ends with the killing of the Roman garrison of Jerusalem (a'; 449-456). These two killings are indeed significant in the process towards war with Rome, but the five parts in between these two parts rather put the emphasis on faction struggle among the Judeans. That is, the second part (b) deals with Eleazar's decision that caused the conflict between a peace and war faction (422). But Eleazar now disappears from the scene until he shows up again with his action against the tyranny of Menahem, which establishes a sixth action (b') that confirms Eleazar's leadership. In between these two acts, there is a central panel that deals with the advance of the war faction in two episodes. The first of its parts (c) begins with the introduction of some sicarii who arm the rebels, resulting in further sicarii crimes. This action is then interrupted by the introduction of Menahem ( $\mathrm{x}$ ) in order to continue ( $\left.\mathrm{c}^{\prime}\right)$ under his leadership, resulting in a new series of sicarii crimes. As such, a seven-part chiastic structure can be discerned with the introduction of Menahem as its central axis:

53 Thackeray's translation of " $\sigma \tau \dot{\alpha} \sigma \iota \varsigma$ " as "revolt" has been replaced by "faction struggle" to emphasis thematic coherence.

54 Although chiasmus ( $\chi\llcorner\alpha \sigma \mu o ́ s)$ is a rather modern scholarly concept, which is only briefly mentioned in Pseudo-Hermogenes, De inventione 4.3.2 (4th c. CE), examples can be found in older textbooks of rhetoric under the heading of other rhetorical devices for (reversed) parallelism, such as transposition ( $\alpha \nu \tau \mid \mu \varepsilon \tau \alpha \beta ం \lambda \eta \dot{\eta}$ / commutatio); see Quintilian, Inst. 9.3.85 and Rhet. Her. 4.28.39. Moreover, scholars have found many applications in ancient texts; see esp. John W. Welch, ed., Chiasmus in Antiquity: Structures, Analyses, Exegesis (Gerstenberg: Hildesheim, 1981). For chiasmus in the texts of Josephus, see Mason, FJTC, 3, xx-xxii. I have applied Clark's five criteria in the identification of a chiastic structure in this passage, which include aspects of (1) content (with a common theme); (2) form or structure (i.e., its composition); (3) language (esp. keywords); (4) setting (referring to a common space and time); and (5) theology (which is irrelevant for the present passage); see David J. Clarck, “Criteria for Identifying Chiasm," LB 5 (1975): 63-72. 
(a) Killing of the Roman garrison of Masada (408)

(b) Eleazar's decision to refuse sacrifices of foreigners, resulting in factionalism (409-424)

(c) Advance of the war faction, accompanied by sicarii crimes $(425-432)$

(x) Introduction of Menahem (433)

(c') Advance of the rebels under Menahem's leadership, with further sicarii crimes (434-442)

(b) Eleazar's action against Menahem's (443-448)

(a') Killing of the Roman garrison of Jerusalem (449-456)

Taken together, the three ordering devices put emphasis on the killing of the two Roman garrisons, as well as on the actions of Eleazar, a reckless young men, and Menahem, an aspiring tyrant, in a narrative on the progress towards war with Rome and violent factionalism among the Judeans. Climax is achieved by amplifying the increasing violence, including a shift in sicarii crimes from arming rebels to arson and theft and, subsequently, to killings and massacres. In doing so, Josephus only has to mention the word sicarii once to evoke the notion of sicarii crimes among War's audience, enabling him to make further allusions throughout the rest of narrative up to the climax of the killing of the Roman garrison of Jerusalem.

\subsection{J.W. 4.398-409: Massacring Villains in Masada during the Revolt}

The next reference to sicarii appears in the fourth book of War in the context of a minor narrative on the rebel group of Menahem, now led by Eleazar son of Yair at Masada. It deploys the same commonplaces for vituperation as the earlier passages do:

[These] so-called sicarii had taken possession [of Masada...]. Thus, during the feast of unleavened bread-a feast which has been kept by the Judeans in thanksgiving for deliverance ever since their return to their native land on their release from bondage in Egypt-these assassins, eluding under cover of night those who might have obstructed them, made a raiding descent upon a small town called Engaddi. Those of the inhabitants who were capable of resistance were, before they could seize their arms and assemble, dispersed and driven out of the town; those unable to fly, women and children numbering upwards of seven hundred, were massacred. They then rifled the houses, seized the ripest of the crops, and carried off their spoil to Masada. (Josephus, J.W. 4.400, 402-404 [Thackeray, LCL]) 
In addition to the crime of killing (cl. 1, 3.a), there is also plunder (cl. 3.b), while the negative characterisation is achieved by the commonplace of conspiracy: these sicarii sneak up on their victims, "under cover of night," to massacre them during a holy day, which implies sacrilege (in tempus). In addition, there is a double critique of hypocrisy implied: on the one hand, these sicarii legitimate their cause by Judean law, which they actually violate with their killings of Judeans, and, on the other hand, they pretend to fight for "freedom" and against Roman "slavery" (e.g., J.W. 2.264), but their acts had the (ironic) effect that the Judeans "fled from their countrymen to take refuge with aliens and obtained at Roman hands the security which they despaired of finding among their own people" (4.397, cf. 409-410). ${ }^{55}$ The author already hints at this at the beginning of the narrative, when he introduces the setting and remarks that the feast of Unleavened Bread celebrates the Judean "release from bondage" (4.402). In sum, this narrative on sicarii underscores the increasing cruelness, sacrilege and selfish motives: they massacre defenceless Judeans, including women and children, on a holy day for booty. ${ }^{56}$

\subsection{J.W. 7.252-406: Self-Killing in Masada at the End of the Revolt}

The blame of being villainous cut-throats receives further irony in the fourth reference to sicarii, which is a narrative on the siege and fall of the rebel fortress of Masada in the last book of War. The first part of the narrative is occupied with the actual siege (7.275-319) and this is followed by two speeches of Eleazar, the leader of the Masada sicarii. The first speech argues that it is honourable to prefer "death to slavery" (7.323-336), while the second is more generic from the perspective of Greco-Roman philosophy on suicide (341-388).57 For the purpose of the present argument, I focus on the plot of the narrative: the rebels "slaughter their wives, their little ones and themselves" (7.389-397). Although this is a very atypical plot compared to the other siegenarratives in War (which dramatize the destruction of the cities and sufferings of its inhabitants), it is consistent in its rhetoric on sicarii: they take the lives of fellow Judeans, even if these are family, friends, or themselves. The act is

55 For an explicit accusation of hypocrisy against the rebels by War's narrator, see esp. Josephus, J.W. 7.255-256. Such "hypocrisy for appearing virtuous" as a common place for ad hominem vituperation (citation ad. loc.).

${ }_{5} 6$ Cf. the remark that "they embarked on more ambitious enterprises" at the introduction of the narrative; see Josephus, J.W. 4.400-401.

57 Otto Bauernfeind and Otto Michel, "Die Beiden Eleazarreden in Josephus, Bell. 7, 323-336; 7, 341-388," ZNW 58 (1967): 267-72; M. Luz, "Eleazar's Second Speech on Masada and Its Literary Precedents," Rheinisches Museum für Philologie 126 (1983): 25-43. 
symbolically dated to Passover, ${ }^{58}$ just like the raid on Engaddi, and the speech suggests irony by presenting the suicide as a divine punishment-so Josephus ascribes to Eleazar-for "the many wrongs which we [i.e., Eleazar's sicarii] madly dared to inflict upon our countrymen," so "let us pay not to our bitterest foes, the Romans, but to God through the act of our own hands" (7·332-333). Although all members of Eleazar's rebel group died, except for two women and five children (7.399), the Masada episode is not the end of War's sicarii.

\subsection{J.W. 7.407-453: Continued Villainies in the Diaspora after the Revolt}

The last five references to sicarii follow directly after the Masada episode. A "faction of the sicarii who had succeeded in fleeing" showed up in the diaspora community of Alexandria. Again, the use of the label sicarii complies with the Roman legal meaning of the term, as well as the theme of violent political factionalism: these sicarii murdered "Judeans of rank" who opposed them (cl. 1). In reaction, the Judean leaders assembled and advised the people to deliver the sicarii to the Roman governor of Egypt and so it happened. The narrator emphasises the "endurance" and "strength" or "madness" of the sicarii, refusing "under every form of torture... to call Caesar Lord" (7·410-419), which connects with the so-called Fourth Philosophy (see below). Among War's Judean audience, this passage might have been judged positively as martyrdom, ${ }^{59}$ but this interpretation is immediately countered by a moralising sequel. The resistance made the emperor "suspicious" of an "interminable tendency of the Judeans to revolution," whereupon he ordered the destruction of the Judean temple of Onias in Leontopolis (7.420-436), just as this "madness" had led to the destruction of the Jerusalem temple.

The successful cooperation between the Judean leaders and Roman official in Alexandria, however, is juxtaposed with a subsequent narrative of a rebellion in Cyrene (7.437-453). There, the "men of rank" among the Judeans had also appealed to the Roman procurator, Catullus, with an invitation to deal with a group of sicarii led by a certain Jonathan. In contrast to the governor of Alexandria, Catullus used Jonathan as a "handle for injustice:"

[Catullus] instructed Jonathan to name one Alexander, a Judean, with whom he had formerly quarrelled and was now at open enmity, further implicating his wife Berenice in the allegations. These were his first

\footnotetext{
$5^{8}$ I.e. $5^{\text {th }}$ of Xanthicus/Nisan; cf. Josephus, J.W. 4.40. See also Honora H. Chapman, Spectacle and Theater in Josephus's Bellum Judaicum (Stanford: Stanford University Press, 1998), $154-55$.

59 Cf., e.g., 4 Macc 16:14; see Brighton, Sicarii, 135.
} 
victims. After them he slew all the well-to-do Judeans, three thousand persons in all; a step which he thought that he could safely take, as he confiscated their property to the imperial exchequer. (Josephus, J.W. 7.444-445 [Thackeray, LCL])

Catullus also accused leading Judeans of Alexandria and Rome, including Josephus himself, but his "scheme" did not work because Emperor Vespasian investigated the incident. Although the narrative is about a conspiracy, Jonathan is the first sicarius who did not actually murder any Judeans. Instead, his action refers to the fourth and last clause of the lex de sicariis, that is, someone is liable "who, being a magistrate or presiding over a criminal trial, arranged for someone to give false evidence so that an innocent man may be entrapped [and] condemned" (Dig. 48.8.1 [trans. Watson, 1985]). With this last episode, the author has made allusions to all sicarii crimes that are attested in the lex de sicariis, so that War's account can end with a moralising conclusion (of book 7 and War as a whole): Jonathan was "tortured and then burnt alive," while Catullus, who got away with it thanks to imperial clemency, eventually got "a complicated and incurable disease and came to a miserable end," serving as "a demonstration, no less striking than any, how God in his providence inflicts punishment on the wicked" (7.444-445 [Thackeray, LCL]) — thus ends War.

Whereas the preceding pages have argued that Josephus applies the lex Cornelia de sicariis as a commonplace in rhetorical vituperation, the following pages will examine how this vituperation fits in War's narrative as a whole. I shall limit myself to three literary-rhetorical tendencies. More specifically, I shall propose that War's sicarii function as a literary figuration that interacts with a gradual rhetorical amplification, which is most explicit in an apostrophic comment and a hyperbolic "disease" metaphor ${ }^{60}$ When this construct is placed in the light of what ancient theorists have to say about the purpose of such

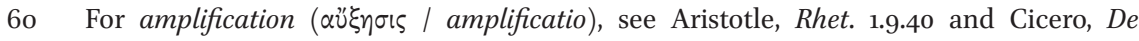
or. 3.26.104-3.27.105 (and the definition above); for apostrophe ( $\alpha \pi \circ \sigma \tau \rho \circ \eta \dot{\eta}$ / aversio, exclamation), see esp. Rhet. Her. 4.15.22 and Quintilian, Inst. 9.2.38-39; for hyper-

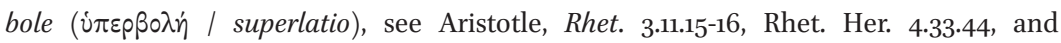
Quintilian, Inst. 8.6.67-76; for metaphor ( $\mu \varepsilon \tau \alpha \varphi \circ \rho \alpha$ / translatio), see Rhet. Her. 4.34.45 and Quintilian, Inst. 8.6.4-18. 
rhetorical devices, it is possible to gain insight into War's more general rhetorical strategy. In addition, I shall argue that the connection between War's sicarii and the so-called Fourth Philosophy is part of the same strategy.

\subsection{The First to Set the Example}

Crucial to understanding the function of War's vituperation against sicarii is Josephus's emotional appeal to his audience, that is, an exclamatory rhetorical apostrophe - a direct speech to his audience - in the last book of War (7.254262). The passage retrospectively reflects on the crimes of the sicarii and the war party during the outbreak of the revolt, ${ }^{61}$ concluding that:

The sicarii were the first to set the example of this lawlessness and cruelty to their kinsmen, leaving no word unspoken to insult, no deed untried to ruin, the victims of their conspiracy. (Josephus, J.W. 7.262 [Thackeray, LCL])

This rhetorical apostrophe is not randomly placed, nor is this claim an accidental hyperbole. The author puts the sicarii at the centre of his vituperation against War's villains by way of introduction to the Masada episode in book 7

61 The $\tau o ́ \tau \varepsilon$ and its subsequent comment at Josephus, J.W. 7.254-258 are often interpreted as referring to the time of Judas (i.e., $6 \mathrm{CE}$ ). This is a misreading of the comment which ignores the habit of Josephus to add biographical information when he introduces a new actor, as Eleazar here, who is introduced as a descendant of Judas. As Brighton, Sicarii, 50-53, points out, "Josephus tells us of no such criminal activity at all-robbery, plunder, and arson-during the time of Judas in $6 \mathrm{CE}_{\text {” }}$ Brighton suggests that "we do read of the Sicarii committing precisely these crimes once they arise during the governorship of Felix," but this narrative only mentions murder during the time of Felix's procuratorship. Instead, the $\tau o$ c $\varepsilon$ refers to the events of the outbreak of the revolt during the governorship of Florus (in $66 \mathrm{CE}$ ), when Eleazar captured Masada, some sicarii armed insurgents and rebels plundered and burned buildings. I thus propose the following reading of the comment: "[The] fortress ... called Masada; and the sicarii who had occupied it had at their head a man of influence named Eleazar. [He was a descendant of Judas, etc.] ... For in those days [i.e., in $66 \mathrm{CE}$, when Masada was captured, see 2.408] the sicarii clubbed together [cf. 2.425] against those who consented to submit to Rome and in every way treated them as enemies [i.e., their attack on the peace faction led by Ananias], plundering their property, rounding up their cattle, and setting fire to their habitations [i.e., the burning of palaces and destruction of debt securities at 2.426-430] protesting that such persons were no other than aliens, who so ignobly sacrificed the hard-won liberty of the Judeans" (7.254-255 [Thackeray, LCL]). See also the parallel comment in Antiquities at 18.25, which explicitly dates these crimes to the time of procurator Florus.

Cf. Rappaport, "Who Were the Sicarii?" 330-34. 
and thus after War's climax of the destruction of Jerusalem and its temple at the end of book 6. At this point, the question of guilt is perhaps most pressing among War's audience: who is to blame for this tragedy? War's author has thus inserted his apostrophe at a strategic moment to maximise its effect, which is, as one scholar explains, to "transform a routine forensic performance into a dynamic verbal assault which could carry an audience on a wave of prejudice against the speaker's adversary." ${ }^{2}$ Thus, by declaiming a list of crimes and $\mathrm{ad}$ hominem accusations, with extensive amplification, ${ }^{63}$ the aim of the apostrophe is to represent the sicarii as the prime villains and catalyst for the crimes committed by the rebels throughout War's account. This claim is supported by the subsequent overview of the tyranny and crimes of War's four main antagonists, including John of Gischala, Simon son of Gioras, the Idumeans and the Zealots (7.263-274). Moreover, the accusation is also in line with the function of the narratives on sicarii as literary figurations of the later crimes by War's main antagonists.

The best example is the assassination of Jonathan the high priest by the first sicarii (J.W. 2.254-257), which foreshadows, respectively, the assassination of Ananias the high priest by Menahem (2.441-442) and that of Ananus the high priest by the Idumaeans (4.314-325). As scholars have pointed out, the death of Ananus, the last protagonist who might have saved the city according to the narrator (4.349), functions as a literary turning-point or peripety of War as a whole, setting in motion a negative spiral in the fortune of the Judeans that results in the disastrous factional struggle between War's four main antagonists and the siege of Jerusalem by the Romans. ${ }^{64}$

Another example is the episode that deals with three "conspirators against the city [of Jerusalem]," including Simon son of Gioras and John of Gischala, who, in the course of attacking each other, plundered the city and burned its storehouse (J.W. 5.21-26). This plundering and arson (i.e., cl. 2 and 3 of the lex de sicariis) is foreshadowed by the same crimes that were committed by the rebels during the outbreak of the revolt (2.425-432). Again, the loss of the storehouse functions as a major setback in the fortune of the Judeans or, as the

62 Stephen Usher, “Apostrophe in Greek Oratory," Rhetorica 28 (2010): 351-62, at 362.

63 As Cicero explains, "amplification... can be used to make one's speech not only increase the importance of a subject and raise it to a higher level... or arousing emotion [for which]... amplification is most effective... Even more important is...laudation and censure [laudandi et vituperandi]; for nothing is more effective for the development and amplification [exaggerandam et amplificandum] of a speech than to be able to use both of these in the fullest abundance" (Cicero, De or. 3.26.104-3.27.105 [Rackham, LCL]; cf. Aristotle, Rhet. 1.9.40).

64 See esp. Mader, Josephus and the Politics of Historiography, 99-100. 
Josephus concludes: "through famine certainly the city fell, a fate which would have been practically impossible, had they [i.e., Simon and John] not prepared the way for it themselves" (J.W. 5.24-26 [Thackery, LCL]).

A more general example of a literary figuration can be found in the repetition of comparable narrative settings, action, and word-usage, such as in the narrative of John's attack on the Zealots:

When the day of unleavened bread came round,... the reputed anniversary of the Judeans first liberation from Egypt, Eleazar and his men partly opened the gates and admitted citizens desiring to worship within the building. But John, making the festival a cloak for his treacherous designs, armed with concealed weapons the less conspicuous of his followers, most of whom were unpurified, and by his earnest endeavours got them stealthily passed into the temple to take prior possession of it. Once in, they cast off their garments and were suddenly revealed as armed men. (Josephus, J.W. 5.99-100; [Thackeray, LCL])

This act resembles three narratives on sicarii, including the assassination of Jonathan the high priest (J.W. 2.254-257), the arming of insurgents on the temple-square (2.425-429), and the massacre at Engaddi (4.398-409). Firstly, there is the basic description of War's sicarii, which is "villains with concealed weapons under their clothing," as well as the commonplaces of conspiracy and secrecy. Secondly, there is a parallel in terms of what takes place, where and when, which is smuggling weapons to the temple square and the killing of fellow Judeans during a holy day (5.103). In addition, there is the repetition of irony that is also found in the narrative of the Engaddi massacre (4.402), that is, the capture of the temple by John, a tyrant, takes place on the Judean holy day that celebrates their "liberation" (5·99).

\subsection{Vectors of a Disease}

Surely, the suggestion that all crimes committed by War's antagonists in Jerusalem originated from a minor group that was banished to an isolated fortress at the edge of the Judean desert is unconvincing. The glue which keeps War's amplification together is a hyperbolic "disease" metaphor, which is a commonplace in Greco-Roman literature, especially in descriptions of the flourishing of immorality within communities. The metaphor is implied in Thucydides's History of the Peloponnesian War (7.27-29). ${ }^{65}$ Josephus articulates the metaphor more explicitly and connects it with sicarii. In the narrative that

65 See Lisa Kallet, "The Diseased Body Politic, Athenian Public Finance, and the Massacre at Mykalessos," AJP 120 (1999): 223-44. Brighton, Sicarii, 59 also quotes other sources, 
includes the first reference to sicarii in War, he comments: "no sooner were these disorders reduced than the inflammation, as in a sick man's body, broke out again in another quarter" (J.W. 2.264). After the raids on Engaddi and other villages by the sicarii, he describes its effect: "the gangster-like, so far quiescent, now began to bestir themselves. And as in the body when inflammation attacks the principal member all the members catch the infection" (4.406 [Thackeray, LCL]). In the last episodes of War, it is also the "madness of the sicarii" which caused faction struggle at Alexandria and Cyrene, after which the simile "like a disease" is added (7.437). As such, War's disease-metaphor serves to make War's amplification convincing by offering - as the author of Rhetorica ad Herennium advises - a "vivid mental picture" (4.34.45; cf. Quintilian, Inst. 8.6.11-12).

In addition, the metaphor of sicarii as vectors of a disease is also implied throughout War's narrative. One example is the career of Simon son of Gioras in relation to the activities of the Masada sicarii. Thus, after War's literary turning point (i.e., the death of Ananus), Josephus laments the "three greatest of calamities" plaguing Jerusalem, namely "war, tyranny, and faction struggle," after which follows the Engaddi massacre by the Masada sicarii as the "fourth misfortune ... on foot to consummate the nation's ruin" (4.397-398). Indeed, the massacre precedes "another war... impending over Jerusalem" (4.503), which introduces the narrative of the rise of Simon son of Gioras (4.503-537, 556-584). Previously, in book 2, Simon, a victor in the battle against Gestius Gallus's legion at Beth-Horon (2.521), was only a minor actor about whom Josephus has little to say, but he does mention him again in a later comment which informs that Ananus the high priest had expelled him from Jerusalem because of his increasing cruelty and tyranny (2.652). ${ }^{66}$ Therefore, Simon had "joined the gangsters who had seized Masada" (4.504, cf. 2.652-654). Their cooperation took the following form:

At first they [i.e., the Masada rebels] regarded him with suspicion ... but afterwards... he was allowed to accompany them on their marauding expeditions and took part in their raids upon the surrounding district. His efforts to tempt them to greater enterprises were, however, unsuccessful; for they had grown accustomed to the fortress and were afraid to venture far, so to speak, from their lair. He, on the contrary, was aspiring

including Herodotus, Hist. 5.28, Sophocles, Ant. 1015, Demosthenes, 3 Philip. 9.39, Sallust, Bell. Cat. 36.5, Tacitus, Ann. 1.43.4, and Hist. 1.25.1.

66 Both "cruelty to citizens" and "aspiring to regnum or tyranny" are common loci for ad hominem invective in Greco-Roman rhetoric; see Craig, "Audience Expectations," 190-91. 
to despotic power and cherishing high ambitions; accordingly on hearing of the death of Ananus, he withdrew to the hills. (Josephus, J.W. 4.505-508 [Thackeray, LCL])

Simon then evolves into one of War's four main antagonists, whose acts resemble that of the sicarii of Masada. He plunders and burns villages throughout the country $\left(4.5^{09-537}, 55^{6-584}\right)$, including the ancient village of Hebron (4.529-534). In this way, the victor of Beth-Horon is only transformed into to the scourge of the hinterland of Jerusalem after an apprenticeship with the Masada group, that is, Eleazar's sicarii kept on spreading their disease without even leaving "their lair."

\subsection{The Sicarii/Fourth Philosophy Connection}

At this point, it is worth reflecting on the connection between the sicarii and the "Fourth Philosophy" in War and Antiquities. The Fourth Philosophy is first introduced in the second book of War as part of a narrative on the organisation of a census in Judea:

A Galilean, named Judas, incited his countrymen to revolt, upbraiding them as cowards for consenting to pay tribute to the Romans and tolerating mortal masters, after having God for their lord. This man was a sophist who founded a sect of his own, having nothing in common with the others. (Josephus, J.W. 4.505-508 [Thackeray, LCL]) ${ }^{67}$

Such a refusal to pay tribute to Rome and call for rebellion, as well as the slogan "no mortal masters, except God," must have served as a red flag among War's Roman audience, especially after the lengthy narrative of a full-scale rebellion under Archelaus (J.W. 2.40-79). It might lead to sympathy with the accusation pronounced by Nicolaus of Damascus in his defence of Archelaus that the Judeans were an ethnos "impatient of all authority and insubordinate towards their sovereigns" (2.92 [Thackeray, LCL]). By way of anticipation, the exposition of Judas in War is remarkably brief and Judas is labelled a "sophist," which is a pejorative term in War. $^{68}$ In addition, Judas's ideology is presented as his "own" philosophical "school" which has "nothing in common" with the other Judean philosophies (2.118). ${ }^{69}$ As Mason points out, Josephus subsequently

\footnotetext{
67 Cf. Josephus, J.W. 2.117-118.

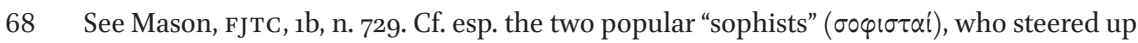
protests under King Herod; see J.W. 1.648-655.

69 For further references and discussion, see Mason, FJTC, 1b, n. 730.
} 
juxtaposes Judas's ideology with a lengthy digression on the three traditional Judean philosophies in which he emphasises the peacefulness of the Essenes as an antithesis and example of the true character of the Judeans. ${ }^{70}$

The introduction of the "Fourth Philosophy" in War, however, does not mention sicarii or any crimen inter sicarios. A connection between both is first implied in book 2 of War with the introduction of Menahem, who is presented as a descendant of Judas and labelled a "sophist," just like Judas (2.445). Although Menahem's group will eventually form the Masada group, it is not labelled sicarii yet, but only indirectly linked with sicarii through narrative connection, that is, with the group that had armed rebels on the temple square (2.408-456; see above). The first explicit connection is made with the introduction of Eleazar son of Yair as the leader of the Masada rebels, who is presented as a descendant of Judas and called a leader of sicarii $(2.433,7.253)$. This is followed by the important retrospective comment on the crimes of the rebels committed during the actual outbreak of the revolt (7.254-262; see above), which also mentions the cause of "freedom" from "Roman slavery" (7.255). The same ideas are then repeated in the speeches of Eleazar, which add the refusal to pay taxes and the claim that the Masada group was "the first to revolt" for this cause (7.323-326). The cause of "independence" and slogan of "God alone as their lord" is then again repeated in the narrative on sicarii in Cyrene and Alexandria (7.410-411). As such, War gradually and retrospectively construes a genealogy of a villainous minority, ${ }^{71}$ including Judas the Galilean (active in $6 \mathrm{CE}$ ), who first developed an anti-Roman ideology, Menahem (active in $66 \mathrm{CE}$ ), who took a leading role in organising the rebellion at Jerusalem, and Eleazar (active in 67-73 CE), who commanded the last bulwark of Judean rebels. ${ }^{72}$

$70 \quad$ Steve Mason, "What Josephus Says About the Essenes in His Judean War," in Text and Artifact in the Religions of Mediterranean Antiquity: Essays in Honour of Peter Richardson, ed. Stephen G. Wilson and Michel Desjardins, Studies in Christianity and Judaism / Études sur le christianisme et le judaïsme (Waterloo: Wilfrid Laurier University Press, 2000), 43467. See also John J. Collins, "Josephus on the Essenes: The Sources of His Information," in Rodgers et al., A Wandering Galilean, 51-72.

71 Cf. Rappaport, "Who Were the Sicarii?" 330-34.

72 Some scholars also include Ezekias the "bandit-chief" (active ca. 45 BCE), who was executed by King Herod (Josephus, J.W. 1.204, Ant. 19.168 and 17.271). They identify Ezekias's son Judas, who rebelled against Herod in 4 вСЕ (see Josephus, J.W. 2.56 and Ant. 17.271-272), with Judas the Galilean who was active in 6 CE. Most scholars, however, consider these two to be different persons; see, e.g., Richard A. Horsley, "Menahem in Jerusalem: A Brief Messianic Episode among the Sicarii-Not 'Zealot Messianism,'” NovT 27 (1985): 334-48, esp. 341-42; Terence L. Donaldson, "Rural Bandits, City Mobs and the 
Antiquities confirms this interpretation. In the first place, the account adds new information, including two more persons to War's rebel dynasty, namely James and Simon, two other sons of Judas, who were executed by procurator Tiberius Alexander (ca. $47 \mathrm{CE}$; see 20.102), and Judas's companion, named "Saddok, a Pharisee" (18.4). In the second place, the passage also includes an emotional reflection by the narrator which is very similar to the one found in War's seventh book. Since the account of Antiquities stops at the time of Florus, leaving out the narratives on the outbreak of the revolt and the siege of Masada among others, it is significant that the rhetorical amplification in War's vituperation against War's villains is exactly placed in the introduction of the Fourth Philosophy. ${ }^{73}$ It claims that Judas and Saddok "sowed the seed of every kind of misery," which is specified as "raids" by "gangsters" and "assassination" of "men of the highest standing" (18.7), and concludes with the same claim again: they "sowed the seed from which sprang strife between factions and the slaughter of fellow citizens" (18.8). Josephus then gives a brief overview of War's account, ${ }^{74}$ after which he addresses his audience:

Here is a lesson that an innovation and reform in ancestral traditions weighs heavily in the scale in leading to the destruction of the congregation of the people. In this case certainly, Judas and Saddok started among us an intrusive fourth school of philosophy; and when they had won an abundance of devotees, they filled the body politic immediately with tumult, also planting the seeds of those troubles which subsequently overtook it, all because of the novelty of this hitherto unknown philosophy. (Josephus, Ant. 18.9-10 [Feldman, LCL])

As in War, Judas's ideology is juxtaposed to an introduction into the three traditional Judean philosophies, but, contrary to War, Josephus adds in Antiquities

Zealots," JSJ 21 (1990): 19-40, esp. 24; David Goodblatt, "Priestly Ideologies of the Judean Resistance," JSQ 3 (1996): 225-49; Rappaport, "Who Were the Sicarii?" 323-42.

73 Contrary to the comment in War (7.254-262; see above), the one in Antiquities is clear on the event it reflects on: "The folly that ensued began to afflict the nation after Gessius Florus, who was governor, had by his overbearing and lawless actions provoked a desperate rebellion against the Romans" (Josephus, Ant. 18.25 [Feldman, LCL]).

74 I quote: "Some were slain in civil strife, for these men madly had recourse to butchery of each other and of themselves from a longing not to be outdone by their opponents; others were slain by the enemy in war [book 2 to 4]; then came the famine, reserved to exhibit the last degree of shamelessness, followed by the storming and razing of cities [book 5] until at last the very temple of God was ravaged by the enemy's fire through this revolt [book 6]" (Josephus, Ant. 18 [Thackeray, LCL]). 
that the Fourth Philosophy "agrees in all other respects with the opinions of the Pharisees" (18.23; cf. 18.4), which is presented as the most popular Judean philosophy (18.4). Nevertheless, Josephus insists that the agreement between the Pharisees and the Fourth Philosophy does not hold for the latter's "passion for liberty" and their slogan that "God alone is their lord and master" (18.18). As such, the framing of Judas's ideology of "no lord but God" as a "fourth," "innovative," or "imported" philosophy (18.9 and 23) serves to frame this ideology as that of a minority of conspiring villains. ${ }^{75}$

\section{Conclusion: Can the Real Sicarii Please Stand Up?}

Rather than reflecting a "fluid use" or a "degree of slippage," I have argued that the author of War used the lex Cornelia de sicariis as a commonplace for rhetorical vituperation. He labels groups sicarii when he alludes to crimes that are punished by this law and characterises them as villainous "cut-throats" with an emphasis on their sacrilegious acts of violence, conspiracy, and cruelty. This vituperation is part of a general rhetorical strategy that aims to reveal the rebel group of Masada as the prime catalysts of violence in Judean politics, as well as the inheritors of a destructive ideology. While Josephus carefully and gradually prepares this disclosure along the way, he strategically locates an explicit formulation of it in a defining moment in War's narrative to shift the full blame for the violence to them.

Such an understanding of War's sicarii has major consequences for historical reconstructions. It rejects the historicity of War's sicarii as a unified rebel group, as well as the sicarii/Fourth Philosophy connection. It requires us to distinguish among five groups that are labelled sicarii and which appear in six distinct contexts:

(1) Those who assassinated Jonathan the high priest and others during the procuratorship of Felix (mid-50S CE), which is narrated in book 2;

(2) Those who armed protesters at the temple during the outbreak of the revolt (66 CE), which is also found in book 2;

(3) The Masada rebels of Eleazar son of Yair at Masada (66-73/74 CE), who were responsible for the massacre at Engaddi in book 4 and who eventually committed a mass-suicide in book 7 ;

75 See Pieter W. van der Horst, "Philosophia epeisaktos: Some Notes on Josephus, A.J. 18.9," in Popović, Jewish Revolt against Rome, 311-22. 
(4) Those who rebelled in the Diaspora community of Alexandria (ca. $72 \mathrm{CE}$ ) in book 7 ;

(5) The movement of Jonathan in Cyrene (ca. $73 \mathrm{CE}$ ), which is also described in book 7 .

Three of these groups are anonymous (i.e., groups 1, 2, and 4) in contrast with the Masada group led by Eleazar son of Yair and the followers of Jonathan of Cyrene, but these two groups can hardly be related. The only plausible connection is the one between the group of Eleazar, who captured Masada, and his cousin Menahem, who armed his followers with weapons from Masada in order to destroy the peace party in Jerusalem. Yet, Menahem is not labelled a sicarius. Josephus only mentions an unidentified group of sicarii who had already armed insurgents on the temple square before Menahem appears on the scene to become "the leader of the revolution." Considering the climactic parallel structure in this narrative, it is possible that Josephus implies that these sicarii were related to Menahem. On the other hand, there is not the slightest indication that those who armed rebels at the temple were related to the previous sicarii who assassinated Jonathan the high-priest. The only element which connects these groups is the term itself and a consistent characterisation, but there are many groups and individuals in War that are consistently characterised and clearly not related, such as the many "tyrants," "bandits," and "revolutionaries."

The modern reader of War is thus confronted with many obscurities throughout War's narrative in trying to find out what had happened, especially regarding crucial events, such as the outbreak of the revolt. Perhaps Josephus deliberately blurred his account in order to anticipate the digging for inaccuracies, contradictions, and falsehood in his account, which could be used by critics in polemics against his person as a historian or former participant in the war. Perhaps they will appear less obscure after further inquiry into War's literary and rhetorical tendencies. For the present study, it suffices to see that Josephus takes much effort to vilify the rebel group of Masada and that he wants them to be condemned as the inheritors of a destructive ideology and "the first to set the example of lawlessness and cruelty to their kinsmen," including the illegal arming of rebels, the killing of opponents, the burning of property, and theft. These crimes provoked the kind of unbridled violence and moral decline that is universally typical for civil wars. The Romans had a word for such villains: sicarii. 